\title{
Competitiveness development, learning orientation, entrepreneurial commitment and business performance in the silk industry
}

\author{
Rostini Rostinia $^{*}$, Wendy Souisa ${ }^{b}$, R. Masmarulan ${ }^{c}$ and Nurfatwa Andriani Yasin ${ }^{c}$ \\ ${ }^{a}$ Universitas Indonesia Timur, Indonesia \\ ${ }^{b}$ Politeknik Negeri Ambon, Indonesia \\ ${ }^{c}$ Sekolah Tinggi Ilmu Ekonomi Tri Dharma Nusantara, Indonesia \\ C H R O N I C L E

\section{A B S T R A C T}

\section{Article history:}

Received: July 20, 2020

Received in revised format:

September 102020

Accepted: October 5, 2020

Available online:

October 5, 2020

Keywords:

Competitiveness Development

Learning Orientation

Entrepreneurial Commitment

Business Performance

\begin{abstract}
This study aims to examine the causal relationship between the variables of business competitiveness development, learning orientation, entrepreneurial commitment, and business performance of the silk industry in Wajo Regency, South Sulawesi Province. The population in this study were all small scale silk industry entrepreneurs, totaling 5,137 businesses spread over 14 districts in Wajo Regency. The size of the research sample based on the Krejcie and Morgan tables is 357 . The data analysis technique uses a structural equation model. The results of the analysis show that the development of business competitiveness and learning orientation partially has a significant effect on entrepreneurial commitment. The development of business competitiveness does not have a significant effect on business performance but learning orientation has a significant effect on business performance. Furthermore, the development of business competitiveness and learning orientation has an indirect effect on business performance through entrepreneurial commitment. The research suggestion is that business development that is oriented towards business performance is not sufficient only based on strengthening knowledge and skills but the main thing is related to the development of the personality of the business actor.
\end{abstract}

(C) 2021 by the authors; licensee Growing Science, Canada

\section{Introduction}

Wajo Regency apart from being a natural silk development area in the upstream sector is also known as a development area in the downstream sector or the spinning and weaving industry, so it can be said that, Wajo Regency is a natural silk development area from upstream to downstream sectors. Non-machine looms (ATBM) are all forms of equipment that can make woven fabrics not driven by machine power but instead moved manually by human power. ATBM is also called the TIB model loom, which comes from the word "testile inrichting Bandung", since this institution was the first to create this loom in Indonesia since 1912. One of the industrial sectors developed by small and medium industries that contributed to the growth of Gross Domestic Product (GDP) until 2016 is the silk industry sub-sector where the average national silk production growth reaches 10\%-15\% per year (BPS Sulsel, 2019). During the last three years, the average growth in silk production has not matched the demand for silk, both nationally and for export to overseas. In line with that, the world's natural silk thread production rate in 2018 only reached around 83,393 tons per year, while the world's demand for natural silk. reaching around 92,743 tons per year, so there is still a considerable shortage. Domestic production of natural silk is less than 500 tons per year, while domestic demand reaches 2,000 tons per year. The growth in demand for world silk is forecasted to be between $2 \%$ and $3 \%$ per annum from existing production levels. There are also those who predict up to a rate of $5 \%$ per year. In Indonesia, it is estimated that the growth rate is $12.24 \%$ of the production that has been achieved (Atmosoedarjo et al., 2000). One of the main producing areas for natural silk, even known as the City of Silk in South Sulawesi, is Wajo Regency. In 2019

* Corresponding author.

E-mail address: rostinirostini620@gmail.com (R. Rostini) 
in Wajo District there were 312.50 hectares of mulberry plantation and 1.5 hectares of mulberry seed gardens. Wajo Regency can absorb 562.25 boxes of silkworm eggs and produce 12,104.80 kg of cocoons and 1,644.00 kg of raw silk with 25 farmer groups consisting of 506 families. In the downstream part, the weaving industry in Wajo Regency as a weaving center involves 5,806 business units employing 17,418 workers with an investment value of IDR 10,931,989,000. There was a simultaneous decrease in the level of cocoon production in Wajo Regency for five consecutive years, from 64,071.00 Kg (2015), 45,843.00 $\mathrm{Kg}(2016), 27,267.15 \mathrm{Kg}(2017), 35,141.60 \mathrm{Kg}$ (2018) and 12,104, $80 \mathrm{Kg}$ in 2019. Based on these backgrounds and conditions, the purpose of this study is to analyze the current condition of the natural silk business in Wajo Regency from various aspects in a holistic manner, although later this research will be limited to the downstream industry.

\subsection{Research Problem}

1. What is the effect of developing competitiveness on entrepreneurial commitment in the Silk Small Industry in Wajo Regency.

2. What is the effect of learning orientation on entrepreneurial commitment in the Silk Small Industry in Wajo Regency.

3. What is the effect of developing competitiveness on business performance in the Silk Small Industry in Wajo Regency

4. What is the effect of learning orientation on business performance in the silk small industry in Wajo Regency

\section{Literature review}

\subsection{Competitiveness Development}

Competitiveness for a product or service is important for a company in increasing and maintaining its existence in seizing market share. Michael Porter (1990) argues that competitiveness is the productivity of the output produced by labor. This theory states that a country gets a competitive advantage if companies in a country are competitive. In line with the enactment of Law Number 33 of 2004 concerning financial balance between the central and regional governments, regional development in Indonesia has entered a new phase. Regional economic development provides opportunities for the development of MSE as a strategic step in increasing and strengthening the basis of the economy, reducing inequality and poverty, and accelerating the recovery of economic growth, equalizing income levels, and increasing the competitiveness and resilience of the national economy (Bergstrand, 1990). The available production factors, such as land, labor and capital can be used as a competitive advantage in the strategies of different industries. These factors can be grouped into a number of broad categories such as human resources, physical, scientific, capital and infrastructure. The competitiveness theorem which also relies on competitive advantage in its development is Thurow's theorem. According to Thurow (2000) in the era of economic globalization, competitive advantage is a factor that cannot be ignored since in the context of competitiveness the commodities to be traded have a comparative advantage in terms of the abundance of factors but are not yet competitive. The development of a business is the responsibility of every entrepreneur or entrepreneur who needs foresight, motivation and creativity (Anoraga, 2007). If this can be done by every entrepreneur, there is great hope of being able to make a business that was originally small to medium scale even into a large business.

\subsection{Learning Orientation}

Learning orientation is one of the right reasons for any organization or company that leads to the formation of a learning organization, so that organizations can act quickly to anticipate changes that can backfire at any time for a company in maintaining its existence. In line with this Sinkula (1994), Narver et al. (2000), learning orientation is an effort made by an organization in the context of developing new knowledge or insights for each member of the organization who has potential behavior. It can be argued that learning is a way to develop the innovation process in the company and even being able to learn from individual company personnel is a continuous advantage for the company, there are 3 components of learning orientation, namely: 1) commitment to learning, 2) shared vision, and 3) various views, the company's success can be achieved quickly if leaders and employees continue to learn from customer needs. Learning orientation is a philosophy adopted by companies that emphasizes learning in organizations. Learning orientation will develop well in an organization that carries out learning. In a learning-oriented organization there will be a process of capacity building that is carried out continuously in order to create an organizational culture that has an important role in creating a better future. Organizational learning has 4 (four) stages of the process, including those suggested by Huber (1991):

1) Information ecquisition is the process of which information applies,

2) Distribution is the process of which information is shared so that all components know that knowledge,

3) Implication is the process of information which is given meaning and transformation into knowledge,

4) Memory is the process of information or knowledge which is stored for further use.

\subsection{Entrepreneurship}

Calvert et al. (2008) argued that entrepreneurship theory includes several theoretical or paradigm approaches which are individual entrepreneurship, small and medium scale enterprises (small and medium-sized enterprises or SMEs), and family businesses. Entrepreneurs are individuals who have the ability to find, assess and take advantage of business opportunities and make them happen through behaviors that lead to creative and innovative activities and are brave enough to accept challenges that are full of risks. Furthermore, the term of entrepreneurship is a character or feature generally attached to an entrepreneur (Souisa., 2018). Entrepreneurs are individuals who have the ability to see, assess and take advantage of business opportunities and behave to create something new through creative and innovative abilities and dare to accept challenges that 
are full of risks based on proactive attitudes, achievement motivation, self-efficacy, and commitment. strong entrepreneurship. Entrepreneurship is actually inherent in its characteristics, namely everyone who is good at seizing and creating opportunities. These opportunities are created through the creation of added value for goods or services (business to live) by applying the characteristics attached to them (Yasin et al., 2019). Some of the factors that encourage someone to become an entrepreneur include: being aware of their potential, experiencing a bitter event or event, and the existence of pressure or demands for life. Choo and Wong (2006) states that the tendency for a person to become an entrepreneur is driven by the capital they have, such as wealth, education, and demographics including: age and marital status.

\subsection{Business Performance}

The definition of performance refers to the level of achievement or achievement of the company in a certain period of time. The company's goals, which consist of: to stay standing or to exist (survive), to get a profit (benefit) and be able to develop (growth), can be achieved if the company has a good performance. The performance (performance) of the company can be seen from the level of sales, the level of profit, the return on capital, the turnover rate and the market share it has achieved. According to Slater and Narver (1994) business performance is measured by profitability compared to predetermined targets. Business or business is often defined as an activity that can provide opportunities for profit or income, through transactions. Generally, we cannot be separated from business or business activities, because our lives are always related to the field of business. Measurement of company performance is carried out to determine the results achieved by the company within a certain time frame. The performance criteria used must be able to be used as a guide for companies in making operational decisions so that strategic objectives are flexible, easy to implement, timely, and understandable by all levels of management (Wisner \& Fawcett, 1991).

\subsection{Conceptual Framework}

Fig. 1 shows the framework of the proposed study of this paper.

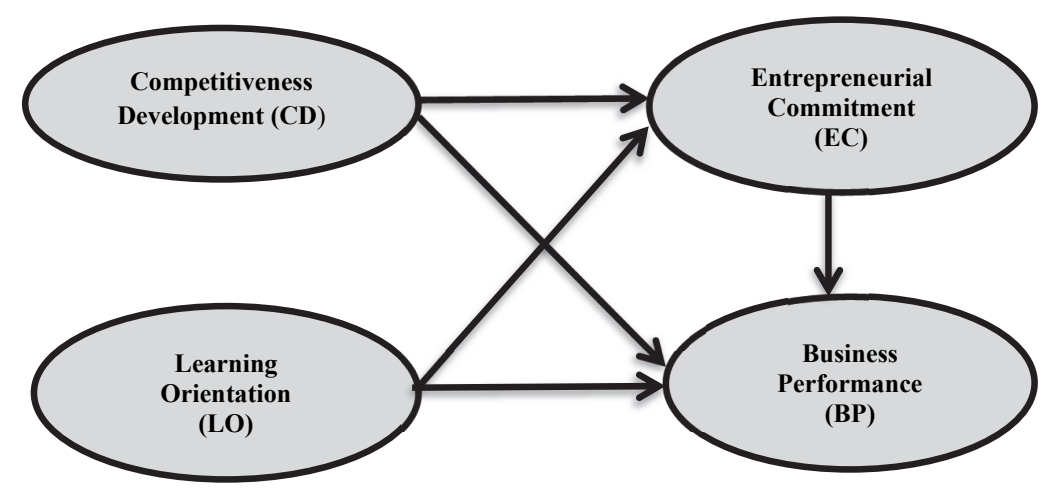

Fig. 1. Concept Framework

\section{Research Methods}

The research is performed in Silk business located in Wajo Regency, South Sulawesi Province. The population in this study were all small-scale silk industry entrepreneurs, totaling 5,137 businesses spread across 14 districts in Wajo Regency, South Sulawesi Province. The size of the research sample based on the Krejcie and Morgan tables was 357. The analysis used in this study is a causal relationship between latent variables, each of which is built through dimensions and indicators. Latent variables include, namely: exogenous variable $(\xi)$ consisting of the Business Competitiveness Development variable $\left(\xi_{1}\right)$, , and Learning Orientation ( $\xi 2)$. Endogenous variables $(\eta)$ consist of Entrepreneurial Orientation ( $\eta 1)$ and Business Performance ( $\eta 2$. The first exogenous variable is the development of competitiveness built through three dimensions, market availability, risk of failure, price determination. The second exogenous variable is learning orientation built through three dimensions, namely: desire to learn, openness to new thinking, and shared vision. Furthermore, the intervening variable is entrepreneurial commitment that is built through commitment to consumers, commitment to the environment, and commitment to business ethics. The endogenous variable is business performance built through two dimensions, financial and non-financial. The total number of research indicators was 33. Then empirical hypothesis testing was carried out using structural equation modeling through the Lisrel Version 8.5 software. SEM analysis aims to explain the direct and indirect effects of exogenous variables on endogenous variables and endogenous variables to other endogenous variables.

\section{Research Results}

\subsection{Structural Equation Modeling}

The analysis model used in this study is Structural Equation Modeling (SEM) which is based on two model approaches, 1) measurement model and 2) structural model. 


\subsection{Measurement Model}

The results of a full model path diagram is given in Fig. 2.

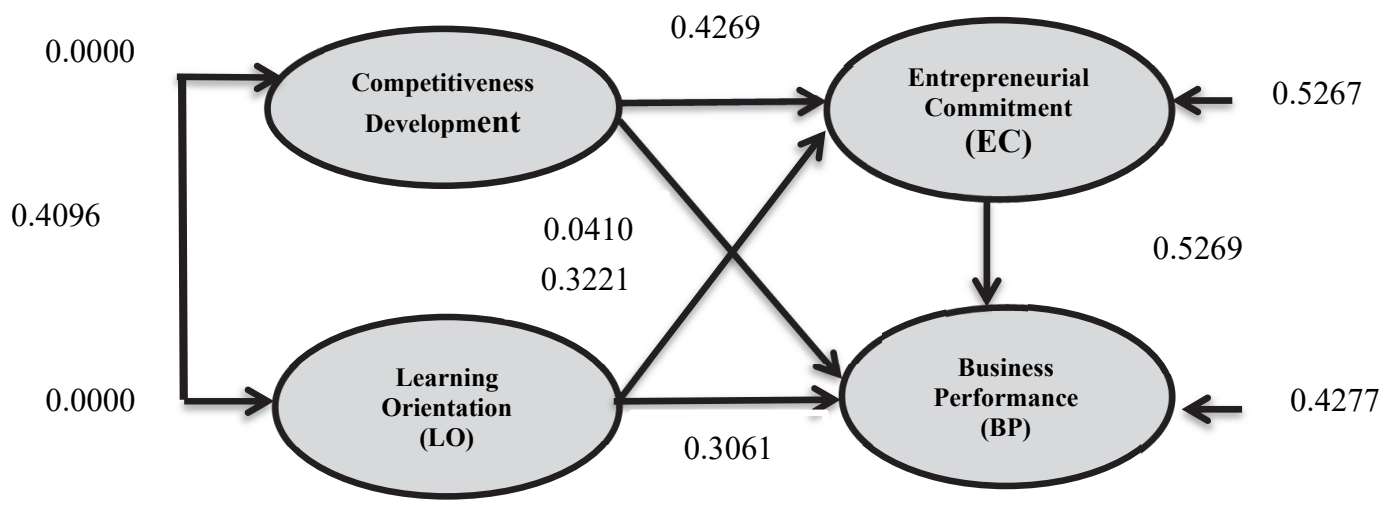

Fig. 2. The results path method

The structural equation between construct or latent variables can be stated as follows.

$$
\begin{gathered}
\eta_{1}=\gamma_{11} \xi_{1}+\gamma_{12} \xi_{2}+\zeta_{1} \\
\eta_{1}=0.4300 \xi_{1}+0.3300 \xi_{2}+0.5700 \\
\eta_{2}=\gamma_{11} \xi_{1}+\gamma_{12} \xi_{2}+\beta_{21} \eta_{1}+\zeta_{2} \\
\eta_{2}=0.530 \xi_{1}+0.041 \xi_{2}+0.310 \eta_{1}+0.420
\end{gathered}
$$

\begin{tabular}{|c|c|c|c|c|c|}
\hline Variabel Laten & Path Coefficient & Direct Influence & $\begin{array}{l}\text { Indirect } \\
\text { Influence }\end{array}$ & T Count & Total \\
\hline \multicolumn{6}{|c|}{ Competitiveness Development } \\
\hline CD ----- EC & 0.4259 & 0.1814 & & 4.5591 & 0.1814 \\
\hline CD ----- EC -----BP & & & 0.0692 & & 0.0692 \\
\hline \multicolumn{6}{|l|}{ Learning Orientation } \\
\hline LO ---- EC & 0.3321 & 0.1103 & & 3.9704 & 0.1103 \\
\hline LO ----- EC ---- BP & & & 0.0692 & & 0.0692 \\
\hline Total Influence (R2) & & 0.2917 & 0.1385 & & 0.4302 \\
\hline
\end{tabular}

Table 1

Contribution of the Influence of Competitiveness Development and Learning Orientation on Entrepreneurial Commitment

\section{The Effect of Business Competitiveness Development on Entrepreneurial Commitment}

The first hypothesis proposed in this study is to test whether there is an effect of developing competitiveness on entrepreneurial commitment in the Silk Small Industry in Wajo Regency. The magnitude of the partial influence of the variable competitiveness development (CD) on entrepreneurial commitment (EC) is obtained through the path coefficient squared with the equation function $=0.43 \xi 1+0.33 \xi 2+0.57$. The value of the variable path coefficient of competitiveness development on entrepreneurial commitment is 0.4259 so that the quadratic value is obtained for the contribution of the determinant value (R2) of 0.1814 or 18.14 perce. This explains that the magnitude of the influence of the competitiveness development variable on entrepreneurial commitment by paying attention to the learning orientation variable is 18.14 percent while the remaining 81.86 percent is determined by other variables. Based on the path value $T$ count in Table 1 , it can be seen that the path coefficient value of 4.5591 is greater than the critical $T$ value of 1.96 at $\alpha: 0.05$, thus it can be argued that the competitiveness development variable has a significant effect on the entrepreneurial commitment variable.

\section{The Effect of Learning Orientation on Entrepreneurial Commitment}

The path coefficient of the learning orientation variable (LO) on entrepreneurial commitment (EC) is 0.3321 . The contribution of the influence of learning orientation is 0.1103 or 11 percent. Based on the path coefficient value of the $T$ value, a value of 3.9704 is obtained or greater than the critical $\mathrm{T}$ value of 1.96 so that it can be argued that the learning orientation variable has an influence on entrepreneurial commitment by paying attention to other variables. Testing simultaneously or together to determine the total contribution of the influence. As for determining the total influence of the variable competitiveness development (X1) and learning orientation (X2) on entrepreneurial commitment (Y) is $0.1814+0.1103=0.2917$. 
Table 2

Contribution of the Influence of Competitiveness Development and Learning Orientation on Business Performance

\begin{tabular}{|c|c|c|c|c|c|}
\hline Variabel Laten & Path Coefficient & $\begin{array}{l}\text { Direct } \\
\text { Influence }\end{array}$ & $\begin{array}{l}\text { Indirect } \\
\text { Influence }\end{array}$ & T Count & Total \\
\hline \multicolumn{6}{|c|}{ Competitiveness Development } \\
\hline CD --- BP & 0.0410 & 0.0017 & & 0.6107 & 0.0017 \\
\hline CD ----- EC -----BP & & & 0.0456 & & 0.0456 \\
\hline CD ----- LO -----BP & & & 0.0431 & & 0.0431 \\
\hline \multicolumn{6}{|l|}{ Learning Orientation } \\
\hline LO ---- BP & 0.3051 & 0.0931 & & 4.6588 & 0.0931 \\
\hline LO ---- EC ---- BP & & & 0.0897 & & 0.0897 \\
\hline LO ---- CD --- -BP & & & 0.0431 & & 0.0431 \\
\hline EC ---- BP & 0.5258 & 0.2765 & & 4.8179 & 0.2765 \\
\hline Total Influence (R2) & & 0.3712 & 0.2214 & & 0.5927 \\
\hline
\end{tabular}

\section{The Effect of Competitiveness Development on Business Performance}

The effect of competitiveness development (CD) on business performance (BP) in the Silk Industry in Wajo Regency. The path coefficient value for the competitiveness development variable is 0.0410 so that to find out the value of the contribution the effect is based on the R2 value or the square value of standardized loading, which is the second rank of the path coefficient value of competitiveness development variable. The contribution of the influence was 0.00168 or 0.17 percent. Based on the calculated path $T$ value in Table 2 , it can be seen that the path coefficient value of 0.6107 is smaller than the critical $T$ value of 1.96 at $\alpha: 0.05$, thus it can be argued that the competitiveness development variable (CD) does not have a significant effect on the business performance variables (BP).

\section{The Effect of Learning Orientation on Business Performance}

The effect of learning orientation (LO) on business performance (BP) in the Silk Small Industry in Wajo Regency is able to adjust to the conditions of the business environment which can change at any time. The path coefficient value of the learning orientation variable on business performance is 0.3051 , so it can be determined that the contribution of the learning orientation influence on business performance is $(\mathrm{R} 2=0.30512)$ or 9.309 percent. Based on the path value of $\mathrm{T}$ count in table 2 , it can be seen that the path coefficient value of 4.6488 is greater than the critical T value of 1.96 at $\alpha: 0.05$, thus it can be argued that the learning orientation variable has a significant effect on the business performance variable. Thus it can be said that partially only learning orientation (LO) has an influence on business performance (BP), while competitiveness development (CD) has no effect on business performance (BP). Simultaneously it shows that the two variables directly have an influence on business performance with an influence contribution of 0.3712 or 37 percent and indirectly 0.2214 or 22.14 percent. The total effect of developing competitiveness and learning orientation, either directly or indirectly, on business performance through entrepreneurial commitment is 0.5927 or 59.3 percent, while the remaining 41 percent comes from other variables not examined in this study.

\section{Discussion}

Seeing the reality in the field, generally small-scale silk business operators still use simple production equipment known as ATBM or non-machine weaving tools. In addition, the production system is still relatively simple, where the integration system between structural and functional components is not well organized. Generally, small-scale silk industry players have structural components consisting of raw materials, production machines and equipment, labor and information that have not been optimally utilized. In addition, the functional components which include supervision, planning, control, and coordination between members and leaders have not been well established. So that generally the impression is still very simple and has an impact on the continuity of production processes that are not smooth or intermittent (intermittent process). This can occur due to non-standard production processes. The results of research by Sahabuddin (2017) state that entrepreneurial commitment has a significant and positive effect on business performance. In line with the results of the analysis, it explains that the development of competitiveness has not been developed as expected to improve business performance. Correspondingly, the involvement of women dominates the silk industry activities compared to men. Where the products produced are still limited to certain market segments and limited market reach by offering products that have not followed market trends. Apart from the limited space and time to make changes in the production process and product motives as well as the availability of working capital, most of the silk business actors do not dare to accept the risk of failure. This indicates that so far business actors have not been able to create meaningful or optimal changes to produce increased business performance.

Competitiveness development has been undertaken so far not optimal to increase market availability, the courage to accept the risk of failure, and determine the right price. So that it has an impact on business performance related to financial and nonfinancial. The facts found in the field indicate that not all business actors have been able to create a wider market availability so that they are only able to meet local market demand. Likewise, not all business actors have the courage to make changes from their hereditary habits, both in terms of more advanced production, marketing, and financial management patterns, so that there has not been any development of better competitiveness. Related to this, where the tools used in the production 
process generally still seem simple, the marketing system is generally still limited to certain circles, as well as pricing that is not based on the right way but rather on a kinship or friendship approach. The desire to learn and try to do business is a message that is always conveyed by some business owners as well as the head of the household to family members who are also employees of the family-owned silk business. They always instill a commitment to entrepreneurship and encourage openmindedness. Organizational learning occurs when organizational members act as learning agents in the organization, responding to changes in the internal and external environment of the organization by detecting and correcting errors in the organizational theory used, and incorporating the results of research carried out in a personal and overall organizational picture. Thus it can be argued that by placing organizational learning as a process through which an individual's knowledge is transferred to the organization so that it can be used by other individuals. It goes on to explain that organizations will learn if through information processing, the potential level of behavior can change. Competitiveness development is not sufficient to be able to improve business performance, without entrepreneurial commitment. In addition to developing competitiveness, a learning orientation is needed in increasing business commitment and performance. According to Narver \& Slater (1994), companies that have made market orientation as an organizational culture will focus on external market needs, the desires of market demand as the basis for formulating strategies for each business unit in the organization and determining the company's success. As an organizational culture, market orientation is conceptualized in terms of levels (degrees) and the levels of market orientation are influenced by various organizational factors (Jaworski \& Kohli, 1993). In the research of Narver \& Slater (1994 it is concluded that market orientation is a determining factor in company performance regardless of the external environmental conditions in which the company operates.

\section{Conclusion}

In terms of achieving business performance, it is not enough to rely solely on competitiveness and learning orientation without being followed by a strong desire to maintain and maintain the values of company goals through entrepreneurial commitment. Entrepreneurial commitment is a person's awareness to maintain and maintain business values and goals by creating something new and creating something different from what already exists, the goal is to achieve added value, both for his business and for other parties. The research suggestion is that business development that is oriented towards business performance is not sufficient only based on strengthening knowledge and skills but the main thing is related to the development of the personality of the business actor.

\section{References}

Anoraga, P. (2007). Pengantar Bisnis: Pengelolaan Bisnis dalam Era Globalisasi. Jakarta: Rineka Cipta

Atmosoedarjo et al. (2000). Sutera Alam Indonesia. Yogyakarta. Yayasan Sarana Wana Jaya.

Bergstrand, J. H. (1990). The Heckscher-Ohlin-Samuelson model, the Linder hypothesis and the determinants of bilateral intraindustry trade. The Economic Journal, 100(403), 1216-1229. www.jstor.org/stable/2233969

Calvert, L. A., Cuervo, M., Lozano, I., Villareal, N., \& Arroyave, J. (2008). Identification of three strains of a virus associated with cassava plants affected by frogskin disease. Journal of phytopathology, 156(11-12), 647-653..

Choo, S., \& Wong, M. (2006). Entrepreneurial intention: triggers and barriers to new venture creations in Singapore. Singapore Management Review, 28(2), 47-64.

Huber, G.P. (1991). Organizational learning. The contributing processes and the literatures. Organization Science, 2(February 1991), 88-115.

Jaworski, B. J., \& Kohli, A. K. (1993). Market orientation: antecedents and consequences. Journal of Marketing, 57(3), 53-70..

Slater, S. F., \& Narver, J. C. (1994). Does competitive environment moderate the market orientation-performance relationship?. Journal of Marketing, 58(1), 46-55.

Narver, J. C., Slater, S. F., \& MacLachlan, D. L. (2000). Total market orientation, business performance, and innovation (No. 116). Cambridge, MA: Marketing Science Institute.

Porter, M. E. (1990). The Competitive Advantage of Nations. The MacMillan Press Ltd.

Sahabuddin, R. (2018). Effect of entrepreneurship commitment to self-efficacy through intention of entrepreneurship and competence. International Journal of Business and Management Science, 8(1), 67-81.

Sinkula, J. M. (1994). Market information processing and organizational learning. Journal of Marketing, 58(1), 35-45..

Souisa, W. (2018). The effects of entrepreneurial orientation and market orientation on business performance. Journal of Entrepreneurship Education, 21(4), 1-6.

Thurow, L. C. (2000). Building wealth: the new rules for individuals, companies, and nations in a knowledge-based economy. American Journal of Economics and Sociology, 59(2), 351-354.

Wisner, J. D., \& Fawcett, S. E. (1991). Linking firm strategy to operating decisions through performance measurement. Production and Inventory Management Journal, 32(3), 5.

Yasin, N. A., Ridjal, S., \& Jjufri, M. (2019). Human capital and entrepreneurship and their impact on the productivity of traditional craftsmen. Revista ESPACIOS, 40(04), 8-20.

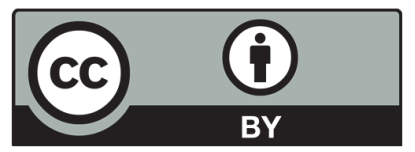

(C) 2020 by the authors; licensee Growing Science, Canada. This is an open access article distributed under the terms and conditions of the Creative Commons Attribution (CC-BY) license (http://creativecommons.org/licenses/by/4.0/). 